\title{
A Chitin Oligosaccharide Deacetylase from Vibrio sp. SN184: Gene Cloning, Overexpression, Purification and Characterization
}

\author{
(Received June 22, 2009; Accepted August 4, 2009) \\ Yusuke Sakamoto, ${ }^{1}$ Eriko Kuno, ${ }^{1}$ Ayumi Tomiyama, ${ }^{1}$ Takako Hirano, ${ }^{1}$ Yasuko Kumaki, ${ }^{1}$ Akina Tanaka, ${ }^{1}$ \\ Hiroshi Kanda, ${ }^{1}$ Kenichi Furuya, ${ }^{1}$ Wataru Hakamata, ${ }^{1}$ Tadatake Oku ${ }^{1}$ and Toshiyuki Nishio,* \\ ${ }^{1}$ Department of Chemistry and Life Science, College of Bioresource Sciences, Nihon University \\ (1866, Kameino, Fujisawa 252-8510, Japan)

\begin{abstract}
The chitinolytic bacterial strain SN184, which produces chitin oligosaccharide deacetylase (COD), was identified a species of the genus Vibrio. The COD gene was cloned from the chromosomal DNA of SN184 and its nucleotide sequence was analyzed. The gene encoded a 427 amino acid protein, including the 22 amino acid signal sequence. The deduced amino acid sequence of this protein showed high similarity to those of several bacterial CODs belonging to carbohydrate esterase family 4. An expression plasmid containing the COD gene of strain SN184 was constructed and inserted into Escherichia coli cells; the recombinant enzyme was secreted into the culture medium with the aid of the signal sequence. The recombinant enzyme was purified from the culture supernatant and its substrate specificity was investigated. These studies confirmed that the recombinant COD hydrolyzed $N$-acetyl groups of the second $N$-acetyl-D-glucosamine residue from the nonreducing-ends of di- $N$-acetylchitobiose and tri- $N$-acetylchitotriose.
\end{abstract}

Key words: chitin oligosaccharide deacetylase, Vibrio, gene cloning, recombinant enzyme, enzyme characterization

Chitin, a water-insoluble $\beta$-(1,4)-linked polymer of $N$ acetyl-D-glucosamine (GlcNAc), is one of the most abundant renewable forms of biomass. In the natural environment, chitin is decomposed mainly by microorganisms that can utilize it as a nutrient source. Various hydrolases are involved in chitin degradation [i.e., chitinase (EC 3.2.1.14), $\beta$ - $N$-acetylhexosaminidase (EC 3.2.1.52), chitin deacetylase (EC 3.5.1.41) and chitin oligosaccharide deacetylase (COD, EC 3.1.1)]. Chitinivorous microorganisms produce water-soluble mono- or oligosaccharides from chitin using one or several of these chitinolytic enzymes, and then transport these soluble saccharides into the cell for further degradation. In a previous paper, we reported that Vibrio parahaemolyticus KN1699 produces the heterodisaccharide $\beta$ - $N$-acetyl-D-glucosaminyl-(1,4)-Dglucosamine (GlcNAc-GlcN) as the primary chitin degradation product using following two types of extracellular enzymes: glycoside hydrolase family 18 chitinase, which produces $N, N^{\prime}$-diacetylchitobiose, $(\mathrm{GlcNAc})_{2}$, from chitin, and carbohydrate esterase (CE) family 4 COD, which hydrolyzes the $N$-acetyl group at the reducing end GlcNAc residue of $(\mathrm{GlcNAc})_{2}{ }^{1-3)}$ Recently, we clarified that GlcNAc-GlcN is not only a nutrient for strain KN1699, but also functions as an inducer of chitinase production by this bacterium. ${ }^{4)}$ Moreover, effect of this heterodisaccharide on the chitinase induction was confirmed also in other chitin-decomposing Vibrio strains harboring CE family $4 \mathrm{COD}$ genes. These findings suggest that CODs involved in the synthesis of this signal compound are key enzymes for chitin catabolism in some species of Vibrio.

* Corresponding author (Tel. +81-466-84-3951, Fax. +81-466-843951, E-mail: nishio.toshiyuki@nihon-u.ac.jp).
To date, aside from COD of strain KN1699, only two CODs, one from Vibrio alginolyticus $\mathrm{H}-8^{5,6)}$ and one from Vibrio cholerae EI Tor N16961, ${ }^{7)}$ have been purified and characterized. Although these three enzymes have high amino acid sequence homologies (80-99\%), their specificities for chitin oligosaccharides are different, indicating the importance of characterizing other microbial CODs. We therefore screened natural sources for bacteria that secrete enzymes that can convert (GlcNAc) $)_{2}$ to GlcNAcGlcN. As a result, we isolated a target bacterium (strain SN184) from the bacteria that adhered on the surface of $\alpha$-chitin flakes (wrapped with tea bag filter paper) sunk in the sea near Tsumekizaki (Shimoda City, Shizuoka Prefecture, Japan). Gram-stain results indicated that strain SN 184 is Gram-negative. The genotype of strain SN184 was investigated by comparing the nucleotide sequence of its $16 \mathrm{~S}$ rDNA (GenBank accession no. AB469367) to the sequence database BLASTN. The results confirmed that the isolate is most closely related to many strains of the genus Vibrio (about 97\% identity). Although we tried to determine the species of this isolate by investigating its physiological characteristics, it was not possible to determine the species of this bacterium using the methodology outlined in Bergey's Manual of Systematic Bacteriology. The bacterium was therefore named Vibrio sp. SN184.

To clone the COD gene of strain SN184, we constructed PCR primers, 5'-CAACCGGTTGCATTATTCGT G-3' (forward primer) and 5'-ACATGATGATAGTAGGG AACAG-3' (reverse primer), from highly conserved nucleotide sequences of upstream and downstream regions around the COD genes of $V$. parahaemolyticus KN1699 (1284 bp, GenBank accession no. AB275387) and V. alginolyticus H-8 (1284 bp, GenBank accession no. AB 

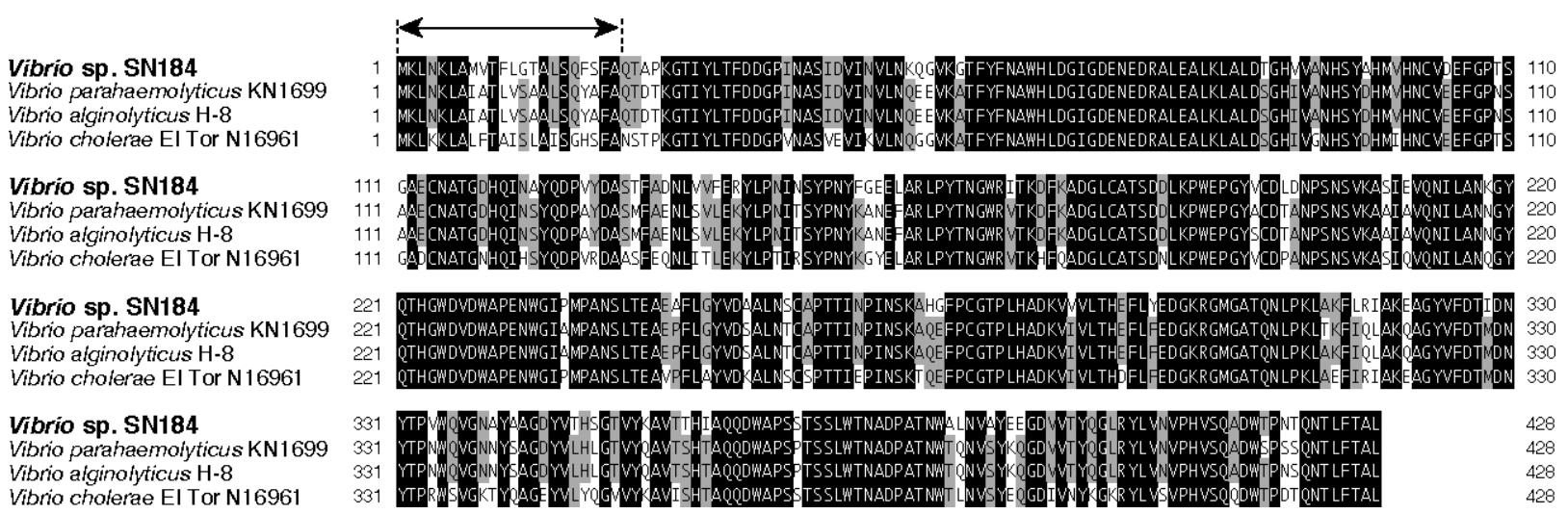

Fig. 1. Alignment of amino acid sequences of putative COD from the nucleotide sequences of the PCR product.

Amino acids highlighted in black and gray indicate identical and highly homologous amino acids, respectively. Double-headed arrows indicate the sequences that were confirmed to encode the secretion signal peptides on the products from COD genes of both $V$. parahaemolyticus KN1699 and V. alginolyticus $\mathrm{H}-8 .^{3,6)}$

055217) and performed PCR (Ex Taq DNA polymerase; 30 cycles: denaturation at $94^{\circ} \mathrm{C}$ for $1 \mathrm{~min}$; annealing at $45^{\circ} \mathrm{C}$ for $1 \mathrm{~min}$; elongation at $72^{\circ} \mathrm{C}$ for $1.5 \mathrm{~min}$ ) using these synthetic primers $(2 \mathrm{pmol})$ and chromosomal DNA (200 ng) extracted from strain SN184 cells. As a result, a PCR product consist of approximately 1500 base pairs was confirmed by agarose gel electrophoresis. From the results of nucleotide sequence analysis, genes (1284 bp) that were presumed to encode $\mathrm{CE}$ family $4 \mathrm{COD}$ were found on this DNA fragment. Nucleotide sequences were determined using a ThermoSequenase Fluorescencelabeled primer cycle sequencing kit (GE Healthcare BioScience, Buckinghamshire, UK) and an automated DNA sequencer DSQ-2000L (Shimadzu Corp., Kyoto, Japan). The amino acid sequence deduced from the nucleotide sequence of this gene showed high similarity (79-86\%) to those of $\mathrm{CE}$ family 4 CODs from $V$. parahaemolyticus $\mathrm{KN} 1699,{ }^{3)} V$. alginolyticus $\mathrm{H}-8^{6)}$ and $V$. cholerae E1 Tor N16961, ${ }^{7}$ clearly demonstrating that strain SN184 harbors a $\mathrm{CE}$ family $4 \mathrm{COD}$ gene (GenBank accession no. $\mathrm{AB}$ 469368) (Fig. 1).

The amount of enzyme produced by strain SN184 is very small, so we used recombinant strategies to overproduce the COD, allowing its characteristics to be investigated. Facile purification of the recombinant COD (rCOD) is achieved only in the absence of large amounts of other proteins from the transformed Escherichia coli cells. Therefore, we engineered a version of rCOD that would be secreted into the E. coli culture medium with the aid of a signal peptide. Amplification of the DNA fragment containing the ribosome-binding sequence and the COD gene that includes the putative signal sequence was performed by PCR (enzyme, cycles and conditions were as described for COD gene cloning) using strain SN184 chromosomal DNA (200 ng) and synthetic oligonucleotide primers (2 pmol), 5'-CGCGGATCC AGGAA TAGAAAATGAAATTAAATAAAC-3' (forward primer) and 5'-CCGCTCGAGCTATAGAGCTGTGAACAAGG$3^{\prime}$ (reverse primer) (underlined letters designate the BamHI site of the forward primer and the XhoI site of the reverse primer. Letters in italics designate added noncomplimentary nucleotides). Resulting PCR products were digested with BamHI (Toyobo Co., Ltd., Osaka, Japan) and XhoI (Nippon Gene Co., Ltd., Tokyo, Japan), then the resulting DNA fragment was ligated into the Bam HI and XhoI sites of pET-21 (+) (Merck, Damstadt, Germany) to yield the expression plasmid. E. coli BL21 (DE 3) was transformed with this plasmid, and the transformants were selected on LB medium-agar plates supplemented with $50 \mu \mathrm{g} / \mathrm{mL}$ ampicillin. E. coli cells harboring the expression plasmid were cultivated at $37^{\circ} \mathrm{C}$ in $200 \mathrm{~mL}$ of LB medium supplemented with $50 \mu \mathrm{g} / \mathrm{mL}$ ampicillin, and the production of rCOD was induced by the addition of isopropy- $\beta$-thiogalactopyranoside (IPTG, final concentration; $1 \mathrm{~mm}$ ). Addition of IPTG to the culture broth immediately promoted the production of rCOD in the $E$. coli cells, while its secretion into the culture medium required more time. After $8 \mathrm{~h}$ cultivation, total COD activity in the culture medium was at the same level as that in E. coli lysates. It was confirmed by SDS-PAGE that the protein (45 $\mathrm{kDa})$ presumed to be rCOD was the main product in the $E$. coli culture medium, while other proteins secreted by the $E$. coli cells were present in very low concentrations (data not shown). These results indicate that the conditions used in the present investigation are favorable for the purification of rCOD. The rCOD was purified from the culture supernatant by $\left(\mathrm{NH}_{4}\right)_{2} \mathrm{SO}_{4}$ precipitation $(80 \%$ saturation) and ion-exchange column chromatography using DEAE-Toyopearl 650M resin (Tosoh Corp., Tokyo, Japan). The rCOD was eluted from the column $(\phi 1.6 \times 30$ $\mathrm{cm}$ ) with a linear gradient of 0 to $0.4 \mathrm{M} \mathrm{NaCl}$ in $20 \mathrm{~mm}$ sodium phosphate buffer ( $\mathrm{pH}$ 7.0). The resulting recombinant protein gave a single band of molecular mass $45 \mathrm{kDa}$ on SDS-PAGE (data not shown). Using the method presented here, rCOD was purified 11.6-fold from the culture supernatant with a total recovery of $11.4 \%$. The $\mathrm{N}$ terminal amino acid sequence of the recombinant protein was determined to be QTAPKGTIYLTF, showing that the signal peptide region (MKLNKLAMVTFLGTALSQFSFA) of the expression product was removed as the protein crossed the E. coli cell membrane. The N-terminal amino acid sequences of the protein were determined using a Model 492 Procise protein sequencer (Applied Biosystems Inc., Foster City, USA).

The rCOD was most active at $\mathrm{pH} 7.0-7.5$ and $45^{\circ} \mathrm{C}$, indicating that COD of strain SN184 is similar to that of 
Table 1. Substrate specificity of rCOD.

\begin{tabular}{lc}
\hline Substrate & $\begin{array}{c}\text { Specific activity } \\
(\mathrm{U} / \mathrm{mg} \text { of protein })\end{array}$ \\
\hline GlcNAc & $\mathrm{ND}^{*}$ \\
$(\mathrm{GlcNAc})_{2}$ & 7.8 \\
$(\mathrm{GlcNAc})_{3}$ & 2.2 \\
$(\mathrm{GlcNAc})_{4}$ & $\mathrm{ND}$ \\
$(\mathrm{GlcNAc})_{5}$ & $\mathrm{ND}$ \\
$(\mathrm{GlcNAc})_{6}$ & $\mathrm{ND}$ \\
\hline
\end{tabular}

GlcNAc and chitin oligosaccharides were purchased from Seikagaku Co. (Japan). The activity of rCOD was assayed by the method previously reported, and the units (U) of enzymatic activity were determined. ${ }^{*} \mathrm{ND}$, no detectable activity.

V. cholerae E1 Tor N16961 in terms of optimum reaction $\mathrm{pH}$ and temperature. In the chitin oligosaccharides used, the recombinant enzyme showed hydrolysis activity for $(\mathrm{GlcNAc})_{2}$, as well as lower activity for $(\mathrm{GlcNAc})_{3}$ at $\mathrm{pH} 7.0$ and $37^{\circ} \mathrm{C}$ (Table 1). To confirm the structure of the reaction products, we purified the compounds produced from (GlcNAc) ${ }_{2}$ and (GlcNAc) ${ }_{3}$ by column chromatography using the cation exchange resin Dowex 50W-X8 (The Dow Chemical Company, Midland, USA) and analyzed their structure by positive ion fast atom bombardment mass spectrometry (FABMS) using a JMX SX-102A instrument (Jeol Ltd., Tokyo, Japan) and ${ }^{1} \mathrm{H}-\mathrm{NMR}$ (400 $\mathrm{MHz}, \quad \mathrm{D}_{2} \mathrm{O}, 20^{\circ} \mathrm{C}$ ) using a Mercury 400 spectrometer (Varian Inc., Palo Alto, USA). The mass spectra of the compound produced from (GlcNAc) $)_{2}$ corresponded to $[\mathrm{M}+$ $\mathrm{H}]^{+}$species at $\mathrm{m} / \mathrm{z}$ of 383 , indicating that this compound is the disaccharide consisting of GlcNAc and GlcN. ${ }^{1} \mathrm{H}-$ NMR signals of this disaccharide corresponded well to those obtained previously with GlcNAc-GlcN, ${ }^{1,499}$ indicating that this disaccharide is GlcNAc-GlcN. This result shows that the position specificity of rCOD for the deacetylation of (GlcNAc) $)_{2}$ is the same as that of CODs from V. parahaemolyticus KN1699, ${ }^{1)}$ V. alginolyticus $\mathrm{H}-8^{5)}$ and $V$. cholerae EI Tor N16961.7) The mass spectra of the compound produced from (GlcNAc) $)_{3}$ corresponded to [M+ $\mathrm{H}]^{+}$species at $\mathrm{m} / \mathrm{z} 586$, indicating that this compound is the trisaccharide consisting of two GlcNAc residues and one GlcN residue. This compound was digested with $A s$ pergillus oryzae $\beta$ - $N$-acetylhexosaminidase (SigmaAldrich Inc., USA), which releases a GlcNAc reside from the non-reducing end of chitin oligosaccharides. ${ }^{10,11)}$ Two reaction products (a and b) were confirmed by silica gel thin layer chromatography (TLC) analysis (Fig. 2). The products were subjected to silica gel preparative layer chromatography (PLC) and isolated from the PLC plate, and their structures were analyzed by FABMS and ${ }^{1} \mathrm{H}-$ NMR. TLC plates (Silica Gel 60, $0.25 \mathrm{~mm}$ ) and PLC plates (Silica Gel 60, $2 \mathrm{~mm}$ ) were obtained from Merck \& Co., Inc. The mass spectra of compound a corresponded to $[\mathrm{M}+\mathrm{H}]^{+}$species at $\mathrm{m} / \mathrm{z}$ of 222 , indicating that this compound is GlcNAc. The mass spectra of compound $\mathbf{b}$ corresponded to $[\mathrm{M}+\mathrm{H}]^{+}$species at $\mathrm{m} / \mathrm{z}$ of 383 , indicating that this compound is the disaccharide consisting of GlcNAc and GlcN. In the ${ }^{1} \mathrm{H}-\mathrm{NMR}$ signals of this disaccharide, chemical shifts (ppm) of $\mathrm{H}-2$ of the reducing end sugar rings appeared at $3.935(\alpha$-anomer) and $3.720(\beta$ anomer), and those of the non-reducing end sugar rings

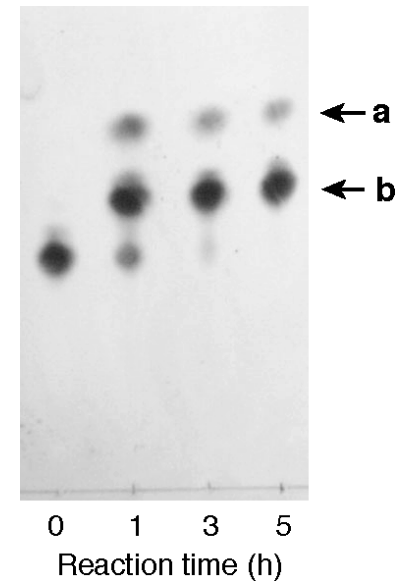

Fig. 2. TLC analysis of compounds obtained by treating the oligosaccharide produced from $(\mathrm{GlcNAc})_{3}$ by rCOD with $A$. oryzae $\beta$ - $N$-acetylhexosaminidase.

$\beta$ - $N$-Acetylhexosaminidase $(1.9 \mathrm{U})$ was added to $200 \mu \mathrm{L}$ of $50 \mathrm{mM}$ sodium phosphate buffer ( $\mathrm{pH} 6.0$ ) containing $3 \mathrm{mg}$ of the trisaccharide, and then the mixture was incubated at $37^{\circ} \mathrm{C}$. At designated time points, $1-\mu \mathrm{L}$ aliquots of the reaction mixture were withdrawn and applied to the TLC plate. The reaction products were developed twice using 5:4:3 (v/v) $n$-butanol/methanol $/ 16 \%$ aqueous ammonia as the mobile phase and visualized by spraying with an aqueous solution of $2.4 \%(\mathrm{w} / \mathrm{v})$ phosphomolybdic acid, $5 \%(\mathrm{v} /$ v) $\mathrm{H}_{2} \mathrm{SO}_{4}$ and $1.5 \%(\mathrm{v} / \mathrm{v}) \mathrm{H}_{3} \mathrm{PO}_{4}$ followed by heating.

appeared at $2.773(\alpha$-anomer) and 2.750 ( $\beta$-anomer). These chemical shift data indicate that compound $\mathbf{b}$ is $\beta$ D-glucosaminyl- $(1 \rightarrow 4)$ - $N$-acetyl-D-glucosamine (GlcNGlcNAc). These data indicate that the oligosaccharide produced from $(\mathrm{GlcNAc})_{3}$ by $\mathrm{rCOD}$ is $N$-acetyl- $\beta$-Dglucosaminyl- $(1 \rightarrow 4)-\beta$-D-glucosaminyl- $(1 \rightarrow 4)-N$-acetyl-Dglucosamine (GlcNAc-GlcN-GlcNAc) and show that the position specificity of $\mathrm{rCOD}$ for the deacetylation of (GlcNAc) $)_{3}$ is the same as that of COD from V. cholerae EI Tor N16961. ${ }^{7)}$ We confirmed that COD from V. parahaemolyticus KN1699 shows high activity against $(\mathrm{GlcNAc})_{2}$, significantly less activity against (GlcNAc) $)_{3}$, and almost no activity against $(\mathrm{GlcNAc})_{4-6 .}{ }^{1)}$ It was reported that COD from $V$. alginolyticus $\mathrm{H}-8$ is specific for (GlcNAc) $)_{2}$ and has no activity against larger chitin oligosaccharides. ${ }^{5)}$ Although (GlcNAc) $)_{2}$ is the best substrate for $V$. cholerae EI Tor N16961 COD, this enzyme also has activity against (GlcNAc) ${ }_{3-6}{ }^{7)}$ These findings indicate that the substrate specificities of Vibrio CODs are diverse even if their primary structure is highly similar. In the present study, it became clear that the substrate specificity of COD we newly isolated from Vibrio sp. SN184 is most similar to that of the V. parahaemolyticus KN1699 enzyme. Recently, we found the CE family 4 COD genes also from Vibrio campbellii and Vibrio proteolyticus. ${ }^{4)} \mathrm{We}$ have a plan to investigate the substrate specificities for CODs of these Vibrios.

This research was supported by grants from the High-Tech Research Center Project of the Ministry of Education, Culture, Sports, Science and Technology of Japan to promote advanced scientific research, and College of Bioresource Sciences, Nihon University. We thank Dr. Kenji Ueda for screening of the bacterium and Naoko Saito, Natsuko Sekino, Mika Hyodo and Nozomi Murayama for their technical assistance. 


\section{REFERENCES}

1 ) K. Kadokura, A. Rokutani, M. Yamamoto, T. Ikegami, H. Sugita, S. Itoi, W. Hakamata, T. Oku and T. Nishio: Purification and characterization of Vibrio parahaemolyticus extracellular chitinase and chitin oligosaccharide deacetylase involved in the production of heterodisaccharide from chitin. Appl. Microbiol. Biotechnol., 75, 357-365 (2007).

2 ) K. Kadokura, Y. Sakamoto, K. Saito, T. Ikegami, T. Hirano, W. Hakamata, T. Oku and T. Nishio: Production and secretion of a recombinant Vibrio parahaemolyticus chitinase by Escherichia coli and its purification from the culture medium. Biosci. Biotechnol. Biochem., 71, 2848-2851 (2007).

3 ) K. Kadokura, Y. Sakamoto, K. Saito, T. Ikegami, T. Hirano, W. Hakamata, T. Oku and T. Nishio: Production of recombinant chitin oligosaccharide deacetylase from Vibrio parahaemolyticus in the culture medium of Escherichia coli cells. Biotechnol. Lett., 29, 1209-1215 (2007).

4 ) T. Hirano, K. Kadokura, T. Ikegami, Y. Shigeta, Y. Kumaki, W. Hakamata, T. Oku and T. Nishio: Heterodisaccharide 4- $O$ ( $N$-acetyl- $\beta$-D-glucosaminyl)-D-glucosamine is a specific inducer of chitinolytic enzyme production in Vibrios harboring chitin oligosaccharide deacetylase genes. Glycobiology, 19, 1046-1053 (2009).

5 ) K. Ohishi, M. Yamagishi, T. Ohta, M. Motosugi, H. Izumida, H. Sano, K. Adachi and T. Miwa: Purification and properties of two deacetylases produced by Vibrio alginolyticus H-8. Biosci. Biotechnol. Biochem., 61, 1113-1117 (1997).

6 ) K. Ohishi, K. Murase, T. Ohta and H. Etoh: Cloning and sequencing of the deacetylase gene from Vibrio alginolyticus H-8. J. Biosci. Biotechnol., 90, 561-563 (2000).

7 ) X. Li, L.-X. Wang, X. Wang and S. Roseman: The chitin catabolic cascade in the marine bacterium Vibrio cholerae: Characterization of a unique chitin oligosaccharide deacetylase. Glycobiology, 17, 1377-1387 (2007).

8 ) J.J. Farmer, J.M. Janda, F.W. Brenner, D.N. Cameron and K. M. Birkhead: Genus I. Vibrio Pacini 1845, $411^{\mathrm{AL}}$. in Bergey's Manual of Systematic Bacteriology, vol. 2. The Proteobacteria. Part B. The Gammaproteobacteria, 2nd Ed., G.M. Garrity, D.J. Brenner, N.R. Krieg and J.T. Staley, eds., Springer, Berlin Heidelberg/New York, pp. 494-546 (2001).

9 ) K. Tokuyasu, H. Ono, K. Hayashi and Y. Mori: Reverse hydrolysis reaction of chitin deacetylase and enzymatic synthesis of $\beta$-D-GlcNAc- $(1 \rightarrow 4)-G l c N$ from chitobiose. Carbohydr. Res., 322, 26-31 (1999).

10) T. Mega, T. Ikenaka and Y. Matsushima: Studies on $N$-acetyl$\beta$-D-glucosaminidase of Aspergillus oryzae. I. Purification and characterization of $N$-acetyl- $\beta$-D-glucosaminidase obtained from Takadiastase. J. Biochem., 68, 109-117 (1970).

11) T. Mega and Y. Matsushima: Comparative studies of three exo- $\beta$-glycosidases of Aspergillus oryzae. J. Biochem., 85, 335-341 (1979).
Vibrio sp. SN184 由来のキチンオリゴ糖デアセチラー ゼの遺伝子クローニング, リコンビナント酵素生産,

\section{およびその精製と諸性質調査}

坂本裕輔 ${ }^{1}$, 久野恵理子 ${ }^{1}$, 富山歩美 ${ }^{1}$, 平野貴子 ${ }^{1}$

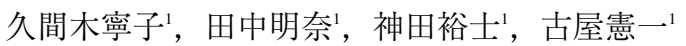

袴田 航 ${ }^{1}$, 奥 忠武 ${ }^{1}$, 西尾俊幸 ${ }^{1}$

${ }^{1}$ 日本大学生物資源科学部生命化学科

(252-8510 藤沢市亀井野 1866)

キチンオリゴ糖デアセチラーゼ (COD， EC 3.1.1) は,

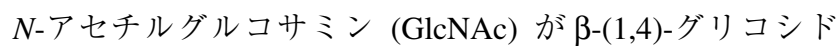
結合で連結したオリゴ糖 (キチンオリゴ糖) の部分脱アセ チル化を触媒する酵素である。以前，われわれは， $(\mathrm{GlcNAc})_{2}$ から CODによって生産されたへテロ 2 糖 (GlcNAc-GlcN) が, 本酵素の遺伝子を有する数種のVibrio 属細菌において，栄養となるばかりでなくキチナーゼ生 産の誘導物質として機能していることを見出した。この ように, COD はある種の細菌のキチン分解代謝において 重要な役割を担っていることがわかった。しかし，COD に関しては，現在のところ 3 種のVibrio 属細菌が生産す るものについての報告しかなく，本酵素の生物機能，特 異性および生物界における分布などについては不明な点 が非常に多い，われわれは，CODに関するより多くの知 見を得るため, 自然界より COD 生産菌のスクリーニング を行ったところ，静岡県下田市の爪木崎沖海底に沈めた キチン片に付着していた細菌から carbohydrate esterase family 4 に属する分泌型 COD を生産する細菌 (Vibrio sp. SN184) を単離することができた，本菌による COD 生産 量はきわめて少なかったため, 分泌シグナル配列を含む COD 遺伝子をクローニングし，大腸菌によりリコンビナ ント酵素 $(\mathrm{rCOD})$ を培養液中に過剰生産させた。得られ た rCODを精製し，GlcNAcとキチンオリゴ糖（重合度； 2-6)に対する特異性を調べたところ, $(\mathrm{GlcNAc})_{2}$ と $(\mathrm{GlcNAc})_{3}$ に対して活性を示した。また，その活性は $(\mathrm{GlcNAc})_{3}$ よりも $(\mathrm{GlcNAc})_{2}$ に対して高かった (約 3 倍). このような特異性は，3 種のVibrio 属細菌由来の COD の 中でもV. parahaemolyticus KN1699のものと類似してい た。 また，本酵素が $(\mathrm{GlcNAc})_{2}$ から GlcNAc-GlcNを， $(\mathrm{GlcNAc})_{3}$ から GlcNAc-GlcN-GlcNAcを生産したことか ら，キチンオリゴ糖の脱アセチル化は，非還元性末端 GlcNAc 残基の隣りの GlcNAc 残基で起こることがわかっ た。この結果は，これまでに報告された 3 種のVibrio 属 細菌の COD の反応位置特異性と同じであった. 